\title{
Afforestation of tropical pasture only marginally affects ecosystem- scale evapotranspiration
}

\section{Journal Article}

Author(s):

Wolf, Sebastian; Eugster, Werner (i); Majorek, Sonja; Buchmann, Nina

Publication date:

2011-12

Permanent link:

https://doi.org/10.3929/ethz-b-000161086

Rights / license:

In Copyright - Non-Commercial Use Permitted

Originally published in:

Ecosystems 14(8), https://doi.org/10.1007/s10021-011-9478-y 


\title{
Afforestation of Tropical Pasture Only Marginally Affects Ecosystem-Scale Evapotranspiration
}

\author{
Sebastian Wolf,* Werner Eugster, Sonja Majorek, and Nina Buchmann
}

Institute of Agricultural Sciences, ETH Zurich, Universitaetsstrasse 2, 8092 Zurich, Switzerland

\begin{abstract}
Evapotranspiration (ET) from tropical ecosystems is a major constituent of the global land-atmosphere water flux and strongly influences the global hydrological cycle. Most previous studies of ecosystem ET have been conducted predominantly in tropical forests, and only few observations cover other tropical land-use types such as pastures, croplands, savannas or plantations. The objectives of our study were: (1) to estimate daily, monthly, and annual ET budgets in a tropical pasture and an adjacent afforestation site, (2) to assess diurnal and seasonal patterns of ET, (3) to investigate environmental controls of ET, and (4) to evaluate the soil infiltration potential. We performed eddy covariance measurements of ecosystem ET in Sardinilla (Panama) from 2007 to 2009. Daily ET $\left(2.6 \pm 1.0 \mathrm{~mm} \mathrm{day}^{-1}\right)$ was significantly lower in the pasture compared to the afforestation site $\left(3.0 \pm 0.9 \mathrm{~mm} \mathrm{day}^{-1}\right)$. The highest ET was
\end{abstract}

\section{INTRODUCTION}

Evapotranspiration (ET) from tropical ecosystems is a major constituent of the global land-atmosphere water flux and largely influences the global hydrological cycle (Werth and Avissar 2004). Given the importance of tropical ecosystems it is indis-

Received 20 January 2011; accepted 9 August 2011; published online 7 September 2011

Author Contributions: SW, WE and NB conceived the study; SW performed the research; SW and SM analyzed data; SW, WE and NB wrote the manuscript.

*Corresponding author; e-mail: sewolf@ethz.ch observed during the wet-dry transition period in both ecosystems. However, differences in daily ET between sites were relatively small, particularly during the wet season. Radiation was the main environmental control of ET at both sites, however, we observed considerable seasonal variation in the strength of this control, which was stronger during the wet compared to the dry season. In 2008, total annual ET was only slightly higher for the afforestation $\left(1114 \mathrm{~mm} \mathrm{y}^{-1}\right)$ than the pasture site $\left(1034 \mathrm{~mm} \mathrm{y}^{-1}\right)$. Our results suggest that afforestation of pasture only marginally increases ecosystem-scale ET 6-8 years after establishment. Differences in soil infiltration potentials between our sites seem to explain this pattern.

Key words: Eddy covariance; water fluxes; water budget; evaporation; soil infiltration potential; Panama; FLUXNET.

pensable to understand how these systems respond to anthropogenic disturbance and changing environmental conditions. To date, seasonal and spatial variations of terrestrial water vapor fluxes in the tropics are not yet fully understood (Hasler and Avissar 2007). Moreover, the area covered by tropical forests is shrinking due to deforestation, whereas managed ecosystems such as plantations, croplands and particularly pastures are becoming more prevalent (Fearnside 2005; Alves and others 2009), supposedly altering patterns and variability of ET. In addition to this anthropogenic land-use change, it is critical to understand the response of 
tropical ET to a changing climate (Fisher and others 2009). Although the exact feedbacks of the hydrological cycle to a changing climate are not well understood (Bates and others 2008; Jung and others 2010), there is evidence that climate change causes an intensification of the water cycle (Huntington 2006). Besides rising temperatures, climate model projections for Amazonia and Latin America indicate a reduction in the total amount of precipitation and an increase in precipitation variability with more frequent extreme dry seasons by the end of this century (IPCC 2007b; Bates and others 2008).

Eddy covariance (EC) measurements of turbulent trace gas fluxes (such as $\mathrm{CO}_{2}$ and $\mathrm{H}_{2} \mathrm{O}$ vapor) between vegetation and atmosphere are widely established within the global measurement network FLUXNET (www.fluxnet.ornl.gov). Despite the importance of tropical ecosystems for the global water cycle, EC measurements in the tropics are still scarce and tropical ecosystems are thus underrepresented within FLUXNET (only 10\% of all registered sites are in the tropics). Most of our knowledge on tropical ET actually originates from one project, the Large Scale Biosphere-Atmosphere Experiment (LBA) in Amazonia, covering primarily tropical forests and savanna ecosystems (Hasler and Avissar 2007; da Rocha and others 2009a, b). Very few additional studies have covered other parts of the tropics so far and their primary focus was on carbon dioxide fluxes (for example, Loescher and others 2003; Merbold and others 2009; Tan and others 2010). Only very few tropical studies have been conducted in non-forested land-use types such as croplands (Sakai and others 2004) and pastures (von Randow and others 2004).

A recently published global synthesis (Beer and others 2010) found that in particular ecosystems dominated by $\mathrm{C}_{4}$ vegetation play a major role for terrestrial gross primary production. Due to the close link between $\mathrm{CO}_{2}$ and $\mathrm{H}_{2} \mathrm{O}$ exchange by stomatal conductivity, this also translates to ET of $\mathrm{C}_{4}$ plants, which are a key component of tropical pasture ecosystems. Consequently, an extension of observations from tropical $\mathrm{C}_{4}$ ecosystems is needed to better understand their role in the global carbon and water cycles.

Furthermore, afforested ecosystems are becoming more abundant in the tropics as they are considered an effective measure to sequester carbon and mitigate anthropogenically induced increases of $\mathrm{CO}_{2}$ concentrations (FAO 2009). In this respect, knowledge about changes in water cycling due to afforestation of tropical pastures is still very limited, especially as most studies so far focused on carbon sequestration of afforestation (Farley and others 2005). The available knowledge can be summarized by two contrasting theories: (1) the 'sponge theory' considers forests to enhance soil infiltration and thus ground water recharge, with gradual releases during dry periods (Malmer and others 2010). Evidence for the 'sponge theory' was provided in a meta-analysis by Farley and others (2005), who reported that the afforestation of grasslands reduced annual surface runoff by $44 \%$ and thus increased the water yield of the forest. (2) The 'compensation theory' assumes that the increased water use of trees in afforestation sites (Scott and others 2005) as compared to the vegetation of former land uses (for example, grasslands) might outcompete these benefits, which then results in relatively minor net changes of the overall water budget due to afforestation. However, comparative measurements to test this theory in the tropics have not been presented so far.

Hence the goal of our study was to address landatmosphere water vapor fluxes (ET) of a tropical pasture in comparison with an adjacent afforested ecosystem with native tree species in Sardinilla (Panama) using the EC technique during the years 2007-2009. The objectives were: (1) to estimate daily, monthly, and annual ET budgets in a tropical pasture and an afforestation site, (2) to assess diurnal and seasonal patterns of ecosystem ET, (3) to investigate environmental controls of ET, and (4) to evaluate the soil infiltration potential.

\section{Materials AND Methods}

\section{Site Description}

Our study was conducted at the Sardinilla research site (Central Panama), located at $9^{\circ} 19^{\prime} \mathrm{N}, 79^{\circ} 38^{\prime} \mathrm{W}$ (70 m a.s.l.) about $40 \mathrm{~km}$ north of Panama City. The site has a semi-humid tropical climate with $2289 \mathrm{~mm}$ annual precipitation and a pronounced dry season, typically lasting from January to April (Figure 1). The length of the dry season varies among years (134 \pm 19 days for 1954-2009; ACP 2010) and is influenced by the El Niño Southern Oscillation (Lachniet 2009). Soils at the site are characterized by high clay contents and thus substantial soil contractions along with desiccation cracks during the dry season (Wolf and others 2011 a). The Sardinilla site was logged in 1952/1953 and used 2 years for agriculture, before it was converted to pasture (Wilsey and others 2002). In 2001, parts of the site were afforested using native tree species ( $7.5 \mathrm{ha}$ ), whereas grazing continued on the remaining pasture (6.5 ha). Pasture vegetation 


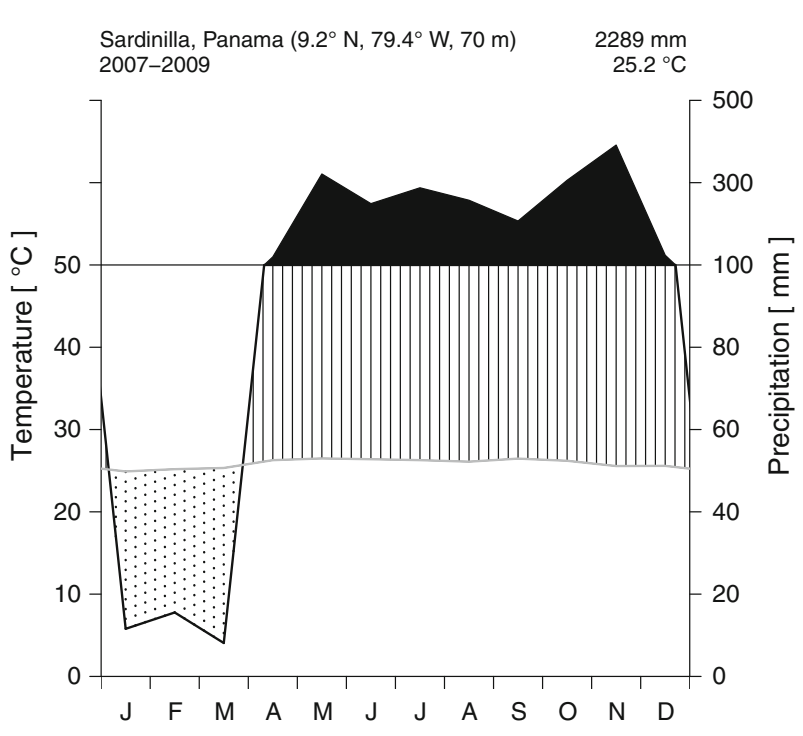

Figure 1. Climate diagram of Sardinilla, based on measurements from April 2007 to December 2009. The gray line indicates mean monthly temperatures, the dotted area denotes periods with arid, and the vertical lines periods with humid climate. In addition, the black shading indicates periods with monthly precipitation exceeding $100 \mathrm{~mm}$. Note the change in scale on the precipitation axis that complies with Walter and Lieth (1960).

is dominated by $\mathrm{C}_{4}$ grasses, consisting of (listed in the order of abundance): Paspalum dilatatum $\left(\mathrm{C}_{4}\right)$, Rhynchospora nervosa (sedge, $\mathrm{C}_{3}$ ), Panicum dichotomiflorum $\left(\mathrm{C}_{4}\right)$, and Sporobolus indicus $\left(\mathrm{C}_{4}\right)$. The afforestation was done with six native tree species: Luehea seemanii, Cordia alliodora, Anacardium excelsum, Hura crepitans, Cedrela odorata, Tabebuia rosea. A moderately dense understory vegetation (shrubs, grasses, and sedges) is present. In 2008, the mean canopy height was $10 \mathrm{~m}$ in the afforestation site and $0.09 \mathrm{~m}$ in the pasture. The afforestation site has an undulating topography (elevation range
$<10 \mathrm{~m}$ ) whereas the pasture is homogeneously flat (slope $<2^{\circ}$ ). Both flux towers are located approximately in the center of each site, with at least $150 \mathrm{~m}$ distance to the adjacent land-use types into the prevailing wind direction (north-east). Footprint analyses (Wolf and others 201la) confirmed that measured fluxes at both sites originated predominantly from the respective land-use type, with a larger footprint fetch for the afforestation (150$200 \mathrm{~m}$ ) compared to $70 \mathrm{~m}$ for the pasture site. Energy balance closure was comparable to other flux tower sites globally, with $84 \%$ for the pasture and $81 \%$ for the afforestation site (Wolf and others 2011a). Further details on the Sardinilla site were published by Wolf and others (201la).

\section{Instrumentation}

Two EC flux towers (Table 1) were used in Sardinilla at a grazed pasture (March 2007 to January 2010) and an adjacent afforestation site (February 2007 to June 2009). Our flux measurement systems consisted of open-path infrared gas analyzers (IRGA, Li-7500, LI-COR, Lincoln, USA) and threedimensional sonic anemometers (CSAT3, Campbell Scientific, Logan, USA). Flux measurements were conducted at $20 \mathrm{~Hz}$ and data acquisition was performed by an industry grade embedded box computer (Advantech ARK-3381, Taipei, Taiwan), running a Debian based Linux operating system (Knoppix 4.0.2, Knopper.Net, Schmalenberg, Germany) and the in-house software sonicreadHS. Additional meteorological measurements included air temperature and relative humidity (MP100A, Rotronic, Bassersdorf, Switzerland), incoming shortwave radiation $\left(R_{\mathrm{G}}, \mathrm{CM} 3\right.$, Kipp \& Zonen, Delft, The Netherlands), net radiation $\left(R_{\mathrm{N}}\right.$; afforestation site: $\mathrm{CNl}$, Middleton Solar, Brunswick, Australia; pasture: Q*7.1, REBS-Radiation and Energy

Table 1. Site Characteristics for the Pasture and Afforestation Flux Towers at Sardinilla

\begin{tabular}{lll}
\hline Site & Pasture & Afforestation \\
\hline Location & $9^{\circ} 18^{\prime} 50^{\prime \prime} \mathrm{N}, 79^{\circ} 37^{\prime} 53^{\prime \prime} \mathrm{W}$ & $9^{\circ} 19^{\prime} 5^{\prime \prime} \mathrm{N}, 79^{\circ} 38^{\prime} 5^{\prime \prime} \mathrm{W}$ \\
Elevation a.s.l. $(\mathrm{m})$ & 68 & 78 \\
Tower height $(\mathrm{m})$ & 3 & 15 \\
Canopy height (m) & 0.09 & $8-12(2007-2009)$ \\
Vegetation & Dominated by C 4 grasses & Six native tree species \\
LAI of canopy & & \\
Dry season & $1.2 \pm 0.43$ & $3.0 \pm 0.62$ \\
$\quad$ Wet season & $2.9 \pm 0.37$ & $5.4 \pm 0.60$ \\
Management & Grazing, herbicide treatment (annually in May) & Selective weed cutting (Dec. 2007 and 2008)
\end{tabular}


Balance Systems, Seattle, USA), photosynthetic photon flux density (PPFD, PAR Lite, Kipp \& Zonen, Delft, The Netherlands), precipitation (10116 rain gauge, TOSS, Potsdam, Germany), soil heat flux at $5 \mathrm{~cm}$ depth (HFP01, Hukseflux, Delft, The Netherlands), soil temperature at $5 \mathrm{~cm}$ depth (TB107, Markasub, Olten, Switzerland), and volumetric soil water content (SWC) at 5 and $30 \mathrm{~cm}$ depth (EC-5, Decagon, Pullman, USA). All meteorological measurements were recorded every $10 \mathrm{~s}$ and stored as half-hourly averages (sums for precipitation) using data loggers (Campbell Scientific, Logan, USA). Precipitation and incoming shortwave radiation were measured at one tower location only $(600 \mathrm{~m}$ distance between both towers). Daily cleaning of sensors and monthly IRGA calibration checks were carried out to assure data quality. Further details on the measurement setup at the Sardinilla site are reported by Wolf and others (2011a).

\section{Data Processing}

Raw flux data were processed to half-hourly averages using the in-house EC software eth-flux (Mauder and others 2008, source code for Unix/Linux systems can be obtained from the authors). Subsequently, half-hourly fluxes were corrected for damping losses (Eugster and Senn 1995) and density fluctuations (Webb and others 1980). We excluded data using the following rejection criteria: (1) Fluxes during optical sensor contamination resulting in increased window dirtiness of the IRGA, based on a $10 \%$ threshold above the mean background value of the respective IRGA; (2) fluxes deviating by more than $100 \%$ between the 30 and $5 \mathrm{~min}$ averages, based on stationarity criteria following Foken and Wichura (1996); (3) statistical outliers exceeding the $\pm 3 \mathrm{SD}$ range of a 14-day running mean window; (4) negative fluxes of $\mathrm{H}_{2} \mathrm{O}$ vapor during daytime while negative $\mathrm{H}_{2} \mathrm{O}$ vapor fluxes were set to zero during nighttime; (5) fluxes during periods with low turbulence conditions based on friction velocity $\left(u^{*}\right)$. We determined seasonal and site-dependent $u^{*}$-thresholds according to the quantitative method by $\mathrm{Gu}$ and others (2005) and Moureaux and others (2006). At the pasture site, this algorithm yielded $u^{*}<0.04 \mathrm{~m} \mathrm{~s}^{-1}$ (dry season), $u^{*}<0.03 \mathrm{~m} \mathrm{~s}^{-1}$ (dry-wet transition), and none during the wet season and wet-dry transition. At the afforestation site, $u^{*}$-thresholds were $u^{*}<0.02 \mathrm{~m} \mathrm{~s}^{-1}$ (dry season), $u^{*}<0.01 \mathrm{~m} \mathrm{~s}^{-1}$ (wet season), $u^{*}<0.05 \mathrm{~m} \mathrm{~s}^{-1}$ (dry-wet transition), and none during the wet-dry transition. These marginal $u^{*}$-thresholds are largely related to the relatively low wind velocities in Sardinilla.
We quality-filtered raw meteorological data to eliminate unrealistic measurements and outliers. During periods of instrument failure, we derived air temperature from virtual temperature measured by the sonic anemometer (regression analysis). Missing precipitation data were supplemented from a nearby station (Salamanca; about $5 \mathrm{~km}$ to the northeast) of the Panama Canal Authority (ACP; STRI 2010). Due to instrument problems at the pasture site, reliable SWC data were only available from the afforestation site.

\section{Gap Filling}

Continuous data of water vapor fluxes for budget assessments were available since June 2007 from both sites. Budget assessments required gap filling of the quality-filtered data. After quality-filtering, $57 \%$ of data of good to excellent quality remained (65\% daytime, $48 \%$ nighttime data) at the pasture site between June 2007 and January 2010. At the afforestation site, $52 \%$ of data of good to excellent quality remained after quality-filtering between June 2007 and June 2009 (68\% daytime, 35\% nighttime data).

Gap filling of daytime net ecosystem $\mathrm{H}_{2} \mathrm{O}$ vapor exchange was based on a significant functional relationship with PPFD (both sites: $P<0.001$ ) using linear least-squares regression with parameters fitted separately for each day. Few remaining gaps in daytime data were filled using a gap model with parameters estimated from the days prior and subsequent to the gaps. All nighttime $\mathrm{H}_{2} \mathrm{O}$ vapor fluxes (measured and missing) were set to zero for gap filling, assuming no significant nocturnal ET due to closure of plant stomata and absent radiation (so-called zero approach, see for example, Novick and others 2009). Gap-filled data of ET were only used for budget assessments whereas process analyses (environmental controls, diurnal cycles) were performed only using measured rates of ET (that is, not considering gap-filled data).

\section{Ancillary Measurements}

Ancillary measurements consisted of leaf area index (LAI) and saturated soil infiltration potential: LAI was measured in weekly to bi-weekly campaigns with a LAI-2000 (LI-COR, Lincoln, USA) from March to July $2009(n=10-30)$. At the afforestation site, LAI was measured separately for the tree canopy (measured at $1 \mathrm{~m}$ above ground) and the total canopy, thus including the understory (measured at ground level). LAI measurements at the afforestation site were corrected for the shading 
effect of tree stems and branches by subtracting the minimum dry season value of tree canopy LAI (DOY 107, 2009; LAI = 0.42). No correction for shading was applied to the LAI measurements at the pasture. We excluded the phenological transition month of May 2009 for seasonal averaging. Due to the short vegetation height and potential displacements with the sensor of the LAI-2000, we have validated our optical LAI measurements at the pasture with an independent bi-weekly assessment of aboveground biomass and found good agreement $\left(R^{2}=0.86, P<0.001\right)$.

Furthermore, we conducted in situ measurements of soil infiltration potential (that is, saturated soil hydraulic conductivity) with 10 replicates at each site once in June 2009, using a hood infiltrometer (UGT, Münchberg, Germany) according to Schwarzel and Punzel (2007). The infiltrometer had an acrylic hood with a diameter of $17.6 \mathrm{~cm}$ and was connected to a conventional Mariotte water supply $(12 \mathrm{~cm}$ diameter and $71.6 \mathrm{~cm}$ height). A u-tube manometer was used to adjust water pressure and prevent overflow. Metal collars were inserted in the soil surface and the interface between the hood and the collar was sealed using quartz sand. Although this method does not yield absolute rates of infiltration, it provides a robust estimate of the maximum saturated soil infiltration potential.

\section{Statistical Analyses and General Conventions}

We used the statistics software package $\mathrm{R}$, version 2.10.0 (R Development Core Team 2009, www. r-project.org) for data analyses. Daytime data were defined as PPFD greater than $5 \mu \mathrm{mol} \mathrm{m} \mathrm{m}^{-2} \mathrm{~s}^{-1}$. The term 'midday' was defined as 11:00-13:00 (UTC). The micrometeorological sign convention was used throughout this article, with fluxes being positive when pointing from the biosphere to the atmosphere and vice versa. Separation of seasons (Table 2) was done based on daily precipitation sums using the methodology described by Wolf and others (2011a): wet season was defined as the time span with no periods of more than four consecutive days without rain, the dry season was defined vice versa. Transition periods mark the time span between both main seasons. In general, only seasons with full data coverage were used for seasonal averaging. When not stated otherwise, reported values denote mean \pm standard deviation. We used a two-sided paired $t$ test to test for statistical differences of means between and within study sites and seasons. When using the term 'seasonal drought', we refer to plant physiological effects of soil moisture deficiency during the dry season. The term 'afforestation' is used instead of 'reforestation' according to the IPCC AR4 definition (IPCC 2007a),

Table 2. Seasonal Overview of Meteorological Variables at Sardinilla, Panama from 2007 to 2009

\begin{tabular}{|c|c|c|c|c|c|c|c|}
\hline & Dates & Length (d) & $P(\mathrm{~mm})$ & SWC $(\%)$ & $R_{\mathrm{G}}\left(\mathrm{W} \mathrm{m}^{-2}\right)$ & ET.Pa (mm) & ET.Aff $(\mathrm{mm})$ \\
\hline \multicolumn{8}{|l|}{2007} \\
\hline Dry-wet transition & 30.03.-22.04. & 24 & 82 & 24 & 370 & - & - \\
\hline Wet season & 23.04.-28.12. & 250 & 2471 & 45 & 286 & $484^{*}$ & $605^{*}$ \\
\hline Wet-dry transition & 29.12.-17.01. & 20 & 17 & 33 & 436 & 75 & 78 \\
\hline Annual sum & & - & 2553 & - & - & $495^{*}$ & $617^{*}$ \\
\hline \multicolumn{8}{|l|}{2008} \\
\hline Dry season & 18.01.-03.04. & 77 & 17 & 24 & 444 & 224 & 274 \\
\hline Dry-wet transition & 04.04.-28.04. & 25 & 51 & 22 & 425 & 61 & 72 \\
\hline Wet season & 29.04.-05.12. & 221 & 1964 & 46 & 291 & 572 & 590 \\
\hline Wet-dry transition & $06.12 .-05.01$ & 31 & 34 & 43 & 398 & 132 & 132 \\
\hline Annual sum & & - & 2074 & - & - & 1034 & 1114 \\
\hline \multicolumn{8}{|l|}{2009} \\
\hline Dry season & 06.01.-19.04. & 104 & 42 & 27 & 439 & 238 & 342 \\
\hline Dry-wet transition & 20.04.-29.04. & 10 & 37 & 24 & 361 & 14 & 22 \\
\hline Wet season & 30.04.-30.11. & 215 & 2122 & $35 *$ & 316 & 529 & $187^{*}$ \\
\hline Wet-dry transition & $01.12 .-03.01$ & 34 & 32 & - & 402 & 112 & - \\
\hline Annual sum & & - & 2233 & - & - & 900 & $570 *$ \\
\hline
\end{tabular}


however, our site in Sardinilla falls into the time threshold since deforestation and could be seen as either of them. Our decision for using the term 'afforestation' is related to the specific site properties (native tree species in mixture without commercial objectives). We refer to the process of land conversion when using the term 'afforestation' and to the specific site when using 'afforestation site/ ecosystem'.

\section{RESUltS}

\section{Ecosystem Water Budgets}

We found only small differences in annual ET between pasture and afforestation sites (Table 2). In 2008 , the pasture returned $1034 \mathrm{~mm}$ or $50 \%$ of annual rainfall $(2074 \mathrm{~mm})$ to the atmosphere via ET, whereas this percentage was slightly lower in $2009(40 \%)$. At the afforestation site, $1114 \mathrm{~mm}$ or $54 \%$ of annual rainfall was returned to the atmosphere via ET in 2008. Moreover, we found large seasonal differences in the amount of water transferred to the atmosphere via ET: During the wet season, only $27 \%$ (pasture) and $28 \%$ (afforestation site) of seasonal rainfalls were lost from the ecosystems via ET and thus, water deficiency (rainfall minus ET) was attributed to surface runoff and infiltration. In both ecosystems, ET losses were almost balanced by rainfall inputs during the drywet transition period, whereas large water deficits were observed during the dry season and the wetdry transition period (Table 2).

\section{Seasonal and Inter-Annual Variations in ET}

Pronounced seasonal variations in ET were observed for both pasture and afforestation ecosystems in Sardinilla, which were predominantly related to seasonal patterns of precipitation and associated radiation due to variations in cloud cover (Table 2).

Variations in monthly water budgets were more pronounced at the pasture than in the afforestation site (Figure 2). We observed a significantly higher monthly ET at the afforestation $(92 \pm 15 \mathrm{~mm}$ month $\left.^{-1}\right)$ compared to the pasture site $(78 \pm$ $\left.19 \mathrm{~mm} \mathrm{month}^{-1}, P<0.001\right)$. Maximum monthly ET was reached in January, with $114 \pm 1 \mathrm{~mm}$ month $^{-1}$ and $120 \pm 2 \mathrm{~mm}$ month ${ }^{-1}$ in the pasture and in the afforestation site, respectively. April and November were the months with the lowest rates of ET at both sites (pasture $51 \pm 9$ and $60 \pm$ $9 \mathrm{~mm} \mathrm{month}{ }^{-1}$, afforestation site $60 \pm 6$ and $79 \pm 8 \mathrm{~mm} \mathrm{month}^{-1}$ ).
Daily ET ranged from 0.4 to $5.2 \mathrm{~mm} \mathrm{day}^{-1}$ (mean $\left.2.6 \pm 1.0 \mathrm{~mm} \mathrm{day}^{-1}\right)$ at the pasture and from 0.6 to $6.0 \mathrm{~mm} \mathrm{day}^{-1}$ (mean $3.0 \pm 0.9 \mathrm{~mm} \mathrm{day}^{-1}$ ) at the afforestation site (Table 3; Figures 2, 3). Daily ET at the afforestation site was only slightly-but significantly-higher than at the pasture during all seasons (Table 3, $P<0.001$ ) except for the wet-dry transition period. The differences between both ecosystems were particularly large during the dry season. Besides the dry season, ET was lowest during the dry-wet transition period when ET was persistently lower at the pasture than at the afforestation site (Figure 3A). Large reductions in ET also occurred in both ecosystems at the end of the wet season and were stronger at the pasture than the afforestation site. Highest rates of ET were observed during the wet-dry transition when neither moisture nor radiation were limiting. We also found inter-annual variations in ET between 2007 and 2009 (Figure 3A): ET in both ecosystems was significantly lower during the prolonged dry season of 2009 compared to the previous year (pasture $P<0.001$; afforestation site $P<0.05$ ), and the decline in 2009 was more substantial in the pasture than the afforestation site.

\section{Diurnal Cycles of ET}

We observed similar patterns in the diurnal cycles of ET between pasture and afforestation sites with

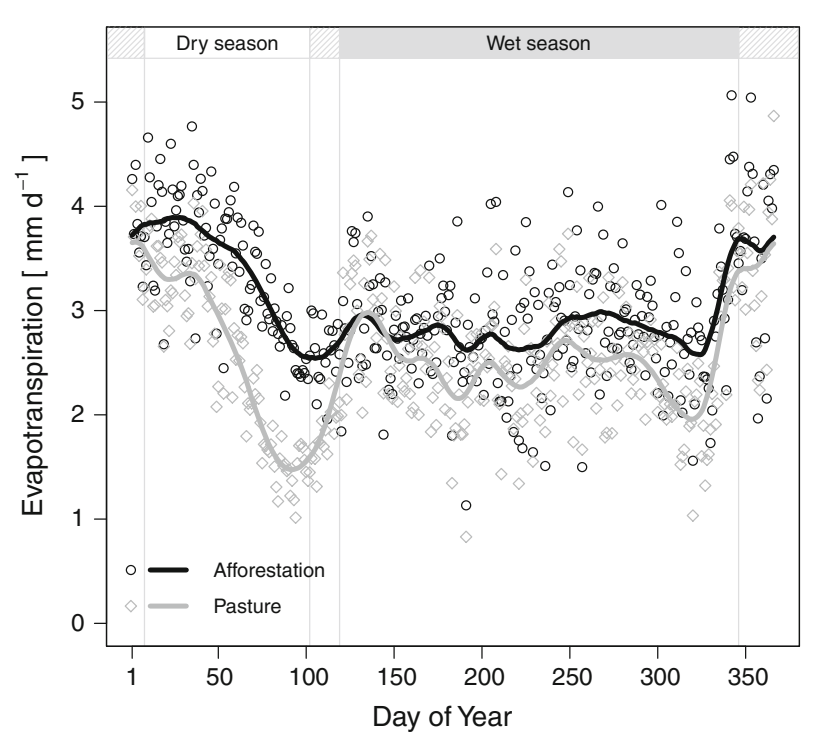

Figure 2. Mean annual course of daily total evapotranspiration (ET) for the pasture and afforestation sites in Sardinilla from 2007 to 2009. Lines denote the monthly running mean. Insets at the top indicate the mean period for different seasons (wet, dry) including transition periods (shaded areas). 
Table 3. Seasonal Averages of Daily Total Evapotranspiration (ET, mm day ${ }^{-1}$ ) over Pasture and Afforestation in Panama from 2007 to 2009

\begin{tabular}{llllll}
\hline & Dry season & Dry-wet transition & Wet season & Wet-dry transition & Total \\
\hline Pasture & $2.5 \pm 1.1$ & $2.1 \pm 0.6$ & $2.5 \pm 1.0$ & $3.8 \pm 0.8$ & $2.6 \pm 1.0$ \\
Afforestation & $3.4 \pm 0.8$ & $2.7 \pm 0.5$ & $2.7 \pm 0.8$ & $4.1 \pm 0.7$ & $3.0 \pm 0.9$ \\
Pasture/Afforestation & $73.5 \%$ & $77.8 \%$ & $92.6 \%$ & $92.7 \%$ & $86.7 \%$
\end{tabular}

Values indicate mean \pm standard deviation. Except during the wet-dry transition period, differences between sites were significant $(P<0.001$, two-sided paired t test). The percentage denotes ET of the pasture compared to the afforestation site.

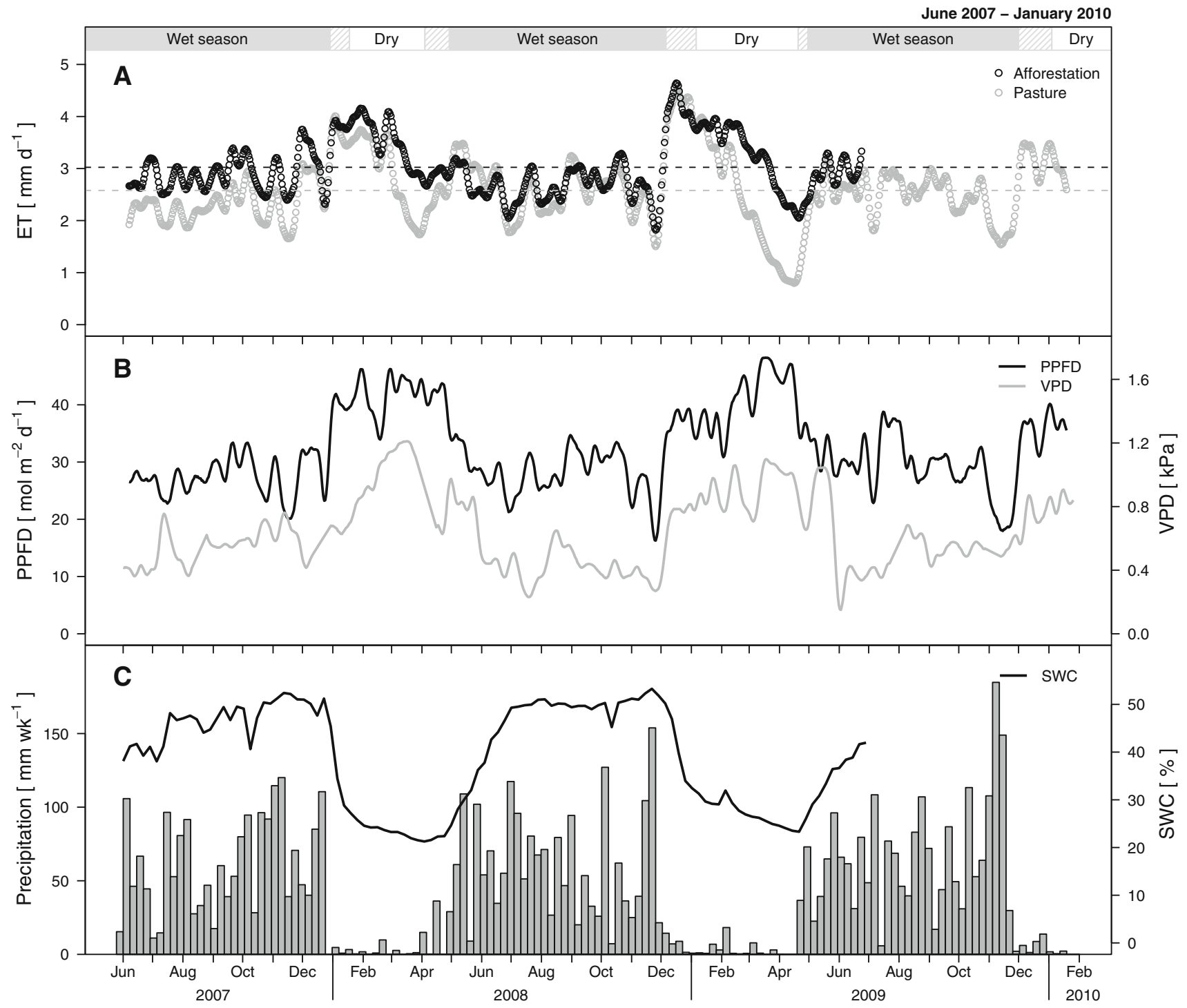

Figure 3. A Daily total evapotranspiration (ET) at the Sardinilla pasture and afforestation sites from June 2007 to January 2010. The dashed gray lines denote daily means. B Daily total photosynthetic photon flux density (PPFD) and vapor pressure deficit (VPD) at the Sardinilla pasture. ET, PPFD, and VPD are displayed as 14-day running means. C Weekly precipitation (gray bars) and weekly mean volumetric soil water content (SWC; afforestation site, at $5 \mathrm{~cm}$ depth) at Sardinilla. Measurements at the afforestation site were discontinued after June 2009. Insets at the top indicate different seasons (wet, dry) including transition periods (shaded areas). 


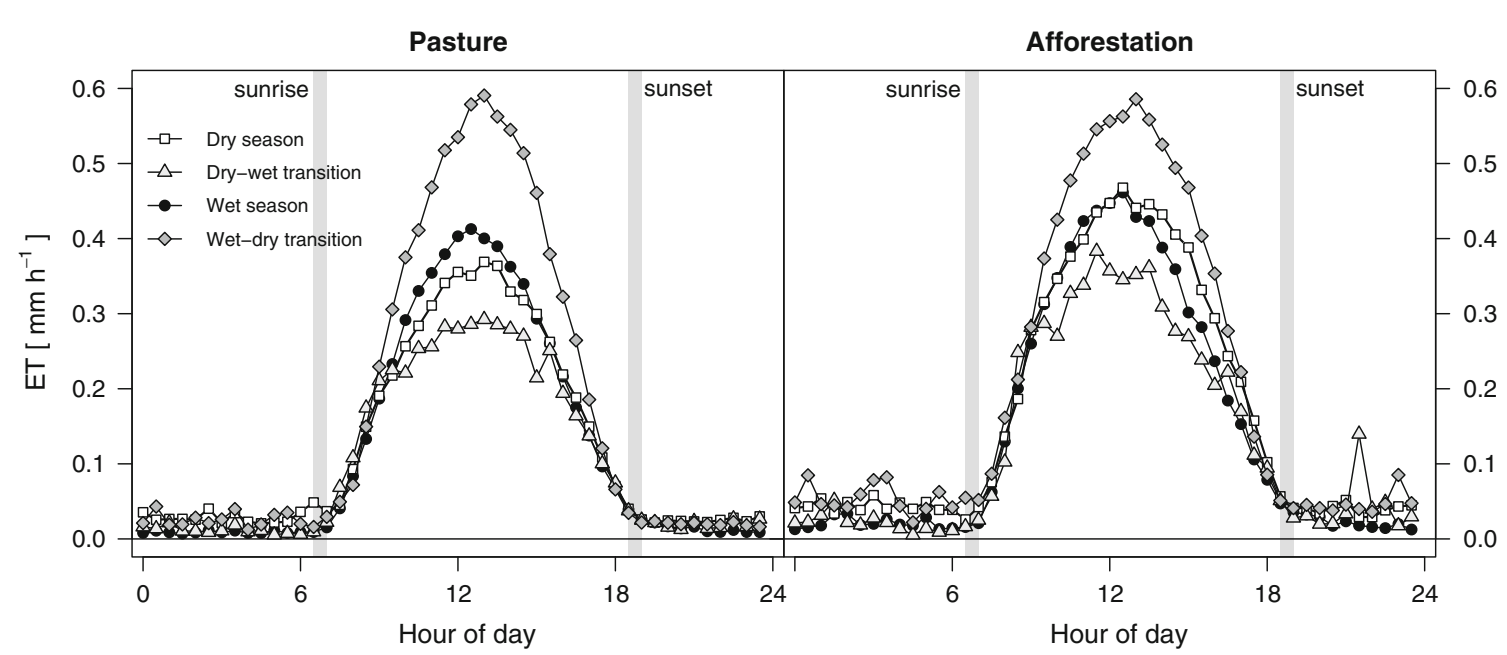

Figure 4. Diurnal cycles of seasonally averaged, non gap-filled evapotranspiration (ET) at the Sardinilla pasture and afforestation sites from 2007 to 2009. Gray bars denote the seasonally varying times of sunrise and sunset.

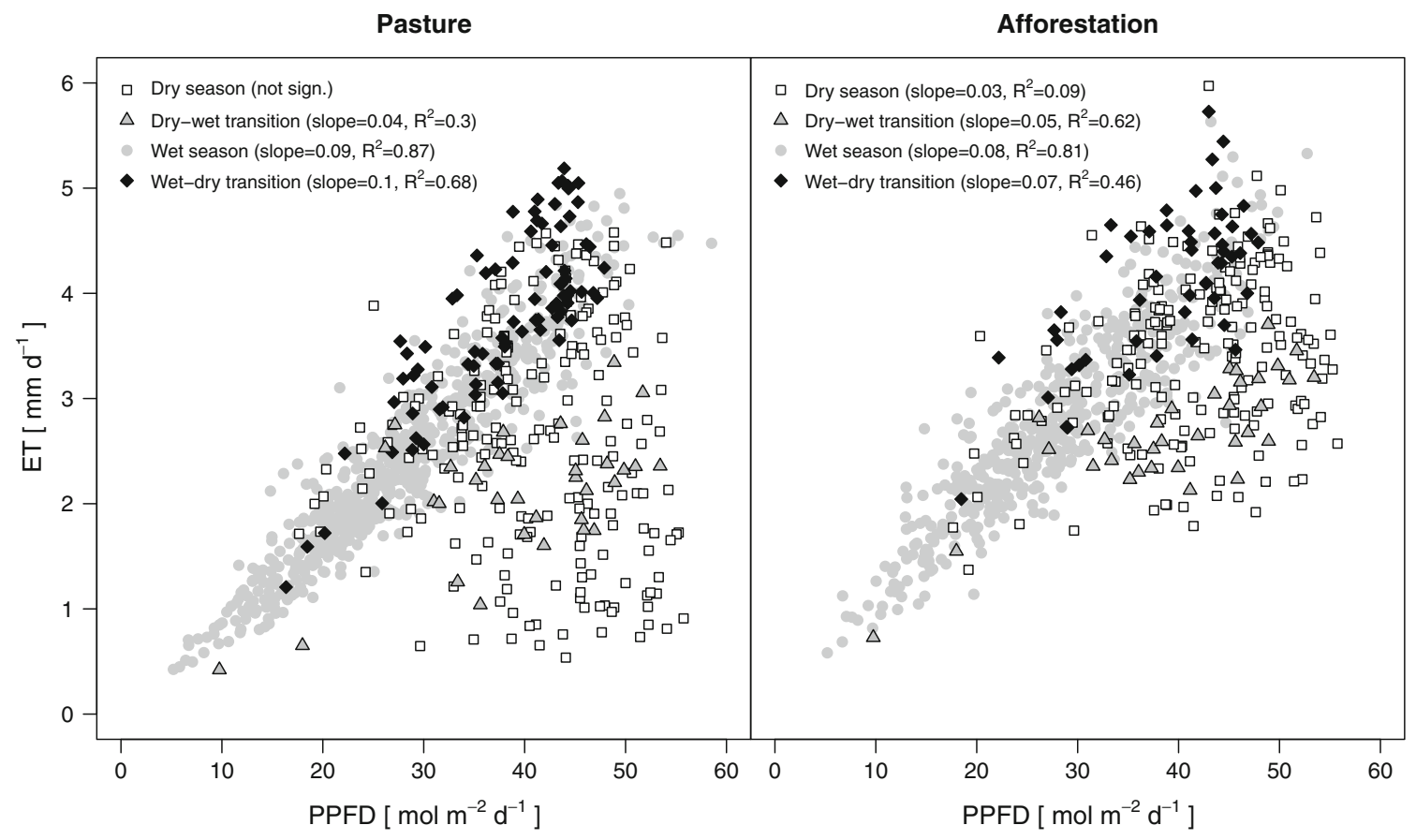

Figure 5. Seasonal variability in the functional relationships of daily total evapotranspiration (ET) and photosynthetic photon flux density (PPFD) at the Sardinilla pasture and afforestation sites from 2007 to 2009. Measurements at the afforestation site were discontinued after June 2009.

strong increases in the morning and with radiation induced maxima around noon. During the wet season, the midday ET of $0.44 \mathrm{~mm} \mathrm{~h}^{-1}$ was significantly higher at the afforestation site than the $0.39 \mathrm{~mm} \mathrm{~h}^{-1}$ measured on the pasture (Figure 4, $P<0.01)$. The highest rates of midday ET were observed during the wet-dry transition period with similar rates in both ecosystems $(0.55$ and $0.54 \mathrm{~mm} \mathrm{~h}^{-1}$ ), but the afforestation site main- tained high ET rates for a longer period over the day than the pasture. Midday ET during the dry season was significantly lower compared to the wet season at the pasture site only $\left(0.35 \mathrm{~mm} \mathrm{~h}^{-1}\right.$, $P<0.001)$. The lowest rates of midday ET were found during the dry-wet transition period and were significantly different between both sites $(P<0.001)$, with $0.28 \mathrm{~mm} \mathrm{~h}^{-1}$ in the pasture and $0.36 \mathrm{~mm} \mathrm{~h}^{-1}$ at the afforestation site. In addition, 
we observed a pronounced midday reduction ('midday depression') in ET during the dry-wet transition period at the afforestation site. During nighttime, measured ET was generally very small but significantly higher at the afforestation (mean $0.03 \mathrm{~mm} \mathrm{~h}^{-1}$ ) than the pasture site (mean $\left.0.01 \mathrm{~mm} \mathrm{~h}^{-1} ; P<0.001\right)$.

\section{Environmental Controls of ET}

Radiation was the main environmental control of ET in Sardinilla, followed by soil moisture, which played an important role during the dry season (Figure 3$)$. At the pasture, net radiation $\left(R_{\mathrm{N}}\right)$ was the strongest predictor for ET and explained $77 \%$ of the variance in half-hourly ET (regression analysis, $P<0.001$; PPFD explained $75 \%$, Figure 5). SWC at the $5 \mathrm{~cm}$ depth was the strongest residual predictor $(3.5 \%)$, followed by soil temperature $(1.5 \%)$ and wind speed $(0.9 \%)$. However, we observed considerable seasonal differences in the environmental controls: during the dry season, $R_{\mathrm{N}}$ explained only $58 \%$ of the variance in ET and the residual predictors were stronger than during the wet season, with SWC (13.5\%) and soil temperature $(21.1 \%)$. The contrary was observed during the wet season, when $R_{\mathrm{N}}$ explained $89 \%$ of the variance in ET and air temperature $(9.6 \%)$ and VPD $(6.5 \%)$ were the strongest residual predictors.

At the afforestation site, radiation measured as PPFD explained $72 \%$ of the variance in ET whereas $R_{\mathrm{N}}$ explained $71 \%$. The strongest residual predictor was SWC at the $30 \mathrm{~cm}$ depth $(5.4 \%)$, followed by soil temperature $(3.1 \%)$ and precipitation $(0.8 \%)$. Seasonal variations in environmental controls were smaller at the afforestation than the pasture site (Figure 5). During the dry season, radiation (measured as PPFD) explained $68 \%$ of the variance in ET at the afforestation site, with SWC at the $30 \mathrm{~cm}$ depth as the strongest residual predictor $(15 \%)$, followed by soil temperature $(7.1 \%)$. On the other hand, during the wet season, radiation (measured as PPFD) explained $77 \%$ of ET whereas soil temperature $(7.1 \%)$ and VPD $(2.3 \%)$ were the strongest residual predictors.

\section{Soil Infiltration Potential}

We observed distinct differences in the soil infiltration potential between pasture and afforestation sites. The afforestation of pasture increased the infiltration potential by a factor of 12 . Infiltration potential was significantly lower at the pasture $\left(114 \pm 65 \mathrm{~mm} \mathrm{~h}^{-1}\right)$ than at the afforestation site $\left(1313 \pm 169 \mathrm{~mm} \mathrm{~h}^{-1} ; \quad P<0.001\right)$. To test the hypothesis of soil compaction as the main cause for these differences, four measurements were taken on walking trails at the afforestation site. The infiltration potential at these disturbed locations $\left(466 \pm 145 \mathrm{~mm} \mathrm{~h}^{-1}\right)$ was significantly lower compared to the undisturbed soil of the afforestation site $(P<0.001)$.

\section{Discussion}

Contrary to our expectations, afforesting pasture lands with native tree species only marginally increased total annual ET in Sardinilla. Annual ET at the Sardinilla afforestation site (2008: $1114 \mathrm{~mm} \mathrm{y}^{-1}$ ) was comparable to the $1135 \mathrm{~mm} \mathrm{y}^{-1}$ reported from an old-growth tropical forest in Brazil (Hutyra and others 2007) and the mean ET of $1096 \mathrm{~mm} \mathrm{y}^{-1}$ from Amazonia (Fisher and others 2009). da Rocha and others (2004) found a higher annual ET in a tropical forest in Tapajos, Brazil $\left(1300 \mathrm{~mm} \mathrm{y}^{-1}\right)$, but a similar ET/precipitation ratio $(60 \%)$. To our knowledge, no annual ET estimates (using the EC technique) are available from other tropical pastures. However, comparable modeled values to our annual ET of pastures ranging between 915 and $1024 \mathrm{~mm} \mathrm{y}^{-1}$ have been reported by Kabat and others (1999) for Amazonian.

\section{Seasonal Variations in ET}

Afforesting a pasture site with native tree species reduced seasonal variations in ET, which were largely related to differences between sites during the dry season. Rooting depth and access to deeper soil water are likely causes for these dry season differences in ET between different tropical landuse types (Jackson and others 1996). Further evidence for this hypothesis is provided by root measurements at the Sardinilla afforestation site (Jefferson Hall; personal communication, unpublished data), indicating a mean rooting depth of $144 \mathrm{~cm}$ at the afforestation site, compared to $10-20 \mathrm{~cm}$ as observed by the authors at the pasture site. The reduction of ET at the end of the wet season (Figure 2, around DOY 320) in both ecosystems was related to persistent precipitation during this wettest period of the year and thus reductions in radiation. In addition, the stronger reduction of ET at the pasture than the afforestation site was linked to overgrazing and associated reductions in aboveground biomass reported by Wolf and others (2011b). Overgrazing also explained the differences between pasture and afforestation sites around DOY 270 (Figure 2).

Compared to other tropical pastures, ET observed at the Sardinilla pasture was similar to those 
reported by Grace and others (1998) from a pasture in Brazil $\left(2.7 \mathrm{~mm} \mathrm{day}^{-1}\right)$. During the dry season, however, ET at the Sardinilla pasture was higher than the $1.9-2.2 \mathrm{~mm} \mathrm{day}^{-1}$ as reported from Amazonia by da Rocha and others (2009a). During the wet season, daily ET rates of 2.2-2.9 $\mathrm{mm}^{\text {day }}{ }^{-1}$ in Amazonia were similar to those in Sardinilla (von Randow and others 2004; da Rocha and others 2009a). Grazing seemed to reduce ET as reported by Santos and others (2004) with a higher daily mean of $3.4 \mathrm{~mm}$ day $^{-1}$ (dry and wet season) for a pasture without grazing in Brazil. When considering alternative tropical land-use types, the lowest values of daily ET in Amazonia were quantified at $1.2 \mathrm{~mm} \mathrm{day}^{-1}$ for bare soil during the dry season with (Sakai and others 2004).

Mean ET observed at the Sardinilla afforestation site was similar compared to the $3-3.5 \mathrm{~mm} \mathrm{day}^{-1}$ reported as an average for tropical forests by Nobre and others (2009), along with seasonal differences ranging from 2.8 to $3.6 \mathrm{~mm} \mathrm{day}^{-1}$ during the wet season and ET rates of 3.3-3.9 mm day ${ }^{-1}$ during the dry season. In general, the highest rates of ET in tropical forests were measured during the dry season when radiation was not inhibited by cloud cover (da Rocha and others 2009b).

\section{Diurnal Cycles}

Surprisingly, we found no significant differences in the diurnal cycle of ET between dry and wet seasons at the afforestation and only small differences at the pasture site. These results are contrary to our observations for carbon dioxide fluxes (see Wolf and others $2011 \mathrm{la}, \mathrm{b}$ ) and suggest a decoupling between transpiration and evaporation during the dry season. As grasses at the pasture became fully senescent at the end of the dry season, ET can be mainly attributed to evaporation from the soil and to re-evaporation of the limited dew formation that formed in the mornings. Component analyses of the energy balance confirmed this hypothesis as the sensible heat flux exceeded the latent heat flux at the pasture during the end of the dry season. An additional water source, that is water import by grazing livestock (urine, perspiration) drinking from a creek located outside the perimeter of the pasture (not within flux tower footprint) was estimated to be less than $0.1 \mathrm{~mm} \mathrm{day}^{-1}$, which is a negligible flux even under conditions of severe overgrazing.

\section{Environmental Controls of ET}

Radiation was the main driver of ecosystem ET in Sardinilla. Similar environmental controls were found by da Rocha and others (2004) with $R_{\mathrm{N}}$ as the main driver of ET in a tropical forest in Tapajos, Brazil, and seasonal patterns of ET closely following radiation. In addition, a synthesis by Fisher and others (2009) found that $R_{\mathrm{N}}$ explained $87 \%$ of the variance in monthly ET of Amazonia, with VPD as the strongest residual predictor. Another study from Amazonia by da Rocha and others (2009a) reported similar controls. In Sardinilla, VPD was of minor relevance and its relevance was clearly restricted to the wet season, when SWC was the strongest residual predictor for ET. Furthermore, we found a stronger decoupling of environmental controls during the dry season at the pasture than at the afforestation site in Sardinilla. The prevalence of surface SWC and soil temperature as residual predictors indicated that evaporation comprised a larger fraction of pasture ET during the dry compared to the wet season. Further evidence for this hypothesis is provided by our LAI and aboveground biomass data which clearly show increasing senescence of grasses with progression of the dry season.

\section{Soil Infiltration Potential}

Our land-use related observations of soil infiltration potentials in Sardinilla are consistent with values from Rondonia (Brazil) reported by Zimmermann and others (2006), with $122 \mathrm{~mm} \mathrm{~h}^{-1}$ for pasture, $834-1155 \mathrm{~mm} \mathrm{~h}^{-1}$ for plantations and $1533 \mathrm{~mm} \mathrm{~h}^{-1}$ reported for primary rainforest. Malmer and others (2010) also reported improved soil infiltration associated with tree planting at other tropical sites across a wide range of rainfall conditions. Soil compaction due to grazing livestock is the main cause of reduced infiltration in pastures (Vanclay 2009). In addition to the removal of grazing, afforesting pastures results in the development of coarse and fine roots that increase soil porosity and thus the infiltration potential. Overall, our results support the 'sponge theory' of enhanced infiltration in forest compared to nonforested land cover (Malmer and others 2010).

With an infiltration potential of less than $8 \%$ at the pasture compared to that at the afforestation site, a much larger percentage of excess water at the pasture is available for surface runoff and evaporation from the surface. As we found only small differences in annual ET between both sites, we conclude that the fraction of evaporation from the soil is higher in the pasture than at the afforestation site. This is supported by two additional facts: (1) Less shading by vegetation provides more available energy reaching the soil surface in the 
pasture, thus increasing soil evaporation (provided that soil conductivity is still high enough). (2) The terrain at the pasture is homogeneously flat (compared to an undulating topography at the afforestation site), which in combination with a lower soil infiltration potential limits surface runoff, thus leaving larger amounts of water that potentially evaporate directly from the soil surface. Consequently, ET does not necessarily increase with afforestation of pastures as more water can infiltrate in forest soils, and less water is lost from the forest via surface runoff or evaporation from the soil surface.

\section{Conclusions}

Our measurements show that afforestation of tropical pastures only marginally increases total annual ET. Reduced infiltration potentials at the pasture site appear to be the likely mechanism responsible for a higher fraction of evaporation from the pasture than the afforestation site. Furthermore, due to the shallow rooting system of grasses compared to trees, pasture vegetation is more sensitive to water limitations during the dry season and becomes fully senescent. Hence, the reduction in ET during the dry season is stronger at the pasture than the afforestation site, and any differences in annual ET are mainly based on dry season reductions.

\section{ACKNOWLEDGMENTS}

Funding for this project was provided by the NorthSouth Centre (former Swiss Centre for International Agriculture) of ETH Zurich. We are grateful to the Smithsonian Tropical Research Institute (STRI) for support at the Sardinilla site, the Meteorology and Hydrology Branch of the Panama Canal Authority (ACP) for providing meteorological data, Jefferson Hall and his project funded by SENACYT for information on rooting depth at the afforestation site, Beate Zimmermann for support with the measurements of soil infiltration potential, José Monteza for tower maintenance, and Rebecca Hiller, Matthias Barthel, and Lutz Merbold for their internal reviews of the manuscript, and Romain Barnard for linguistic support.

\section{REFERENCES}

ACP. 2010. Meteorological Data. Panama Canal Authority (ACP), Meteorology and Hydrology Branch (Republic of Panama), Data provided by Mike Hart.

Alves DS, Morton DC, Batistella M, Roberts DA, Souza C Jr. 2009. The changing rates and patterns of deforestation and land use in Brazilian Amazonia. In: Keller M, Bustamante M, Gash J, Dias PS, Eds. Amazonia and global change. Washington (DC): American Geophysical Union. p 11-23.

Bates BC, Kundzewicz ZW, Wu S, Palutikof JP, Eds. 2008. Climate change and water. technical paper of the intergovernmental panel on climate change. Geneva: IPCC Secretariat.

Beer C, Reichstein M, Tomelleri E, Ciais P, Jung M, Carvalhais N, Rodenbeck C, Arain MA, Baldocchi D, Bonan GB, Bondeau A, Cescatti A, Lasslop G, Lindroth A, Lomas M, Luyssaert S, Margolis H, Oleson KW, Roupsard O, Veenendaal E, Viovy N, Williams C, Woodward FI, Papale D. 2010. Terrestrial gross carbon dioxide uptake: global distribution and covariation with climate. Science 329:834-8.

da Rocha HR, Goulden ML, Miller SD, Menton MC, Pinto L, de Freitas HC, Figueira A. 2004. Seasonality of water and heat fluxes over a tropical forest in eastern Amazonia. Ecol Appl $14: 22-32$

da Rocha H, Manzi AO, Shuttleworth J. 2009a. Evapotranspiration. In: Keller M, Bustamante M, Gash J, Dias PS, Eds. Amazonia and global change. Washington (DC): American Geophysical Union. p 261-72.

da Rocha HR, Manzi AO, Cabral OM, Miller SD, Goulden ML, Saleska SR, Coupe NR, Wofsy SC, Borma LS, Artaxo P, Vourlitis G, Nogueira JS, Cardoso FL, Nobre AD, Kruijt B, Freitas HC, von Randow C, Aguiar RG, Maia JF. 2009b. Patterns of water and heat flux across a biome gradient from tropical forest to savanna in Brazil. J Geophys Res Biogeosci 114

Eugster W, Senn W. 1995. A cospectral correction model for measurement of turbulent $\mathrm{NO}_{2}$ flux. Bound Layer Meteorol $74: 321-40$

FAO. 2009. State of the World's Forests 2009. Food and Agriculture Organization of the United Nations (FAO), Rome, p 168.

Farley KA, Jobbagy EG, Jackson RB. 2005. Effects of afforestation on water yield: a global synthesis with implications for policy. Glob Change Biol 11:1565-76.

Fearnside PM. 2005. Deforestation in Brazilian Amazonia: history, rates, and consequences. Conserv Biol 19:680-8.

Fisher JB, Malhi Y, Bonal D, Da Rocha HR, De Araujo AC, Gamo M, Goulden ML, Hirano T, Huete AR, Kondo H, Kumagai T, Loescher HW, Miller S, Nobre AD, Nouvellon Y, Oberbauer SF, Panuthai S, Roupsard O, Saleska S, Tanaka K, Tanaka N, Tu KP, Von Randow C. 2009. The land-atmosphere water flux in the tropics. Glob Change Biol 15:2694-714.

Foken T, Wichura B. 1996. Tools for quality assessment of surface-based flux measurements. Agric For Meteorol 78:83-105.

Grace J, Lloyd J, Miranda AC, Miranda H, Gash JHC. 1998. Fluxes of carbon dioxide and water vapor over a $\mathrm{C}_{4}$ pasture in south-western Amazonia (Brazil). Aust J Plant Physiol 25:519-30.

Gu LH, Falge EM, Boden T, Baldocchi DD, Black TA, Saleska SR, Suni T, Verma SB, Vesala T, Wofsy SC, Xu LK. 2005. Objective threshold determination for nighttime eddy flux filtering. Agric For Meteorol 128:179-97.

Hasler N, Avissar R. 2007. What controls evapotranspiration in the Amazon basin? J Hydrometeorol 8:380-95.

Huntington TG. 2006. Evidence for intensification of the global water cycle: review and synthesis. J Hydrol 319:83-95.

Hutyra LR, Munger JW, Saleska SR, Gottlieb E, Daube BC, Dunn AL, Amaral DF, de Camargo PB, Wofsy SC. 2007. Seasonal controls on the exchange of carbon and water in an Amazonian 
rain forest. J Geophys Res Biogeosci 112(3):G03008. doi: 10.1029/2006jg000365.

IPCC. 2007a. Climate change 2007: mitigation. Contribution of working group III to the fourth assessment report of the intergovernmental panel on climate change. Cambridge University Press, Cambridge, United Kingdom.

IPCC. 2007b. Climate change 2007: the physical science basis. Contribution of working group I to the fourth assessment report of the intergovernmental panel on climate change. Cambridge University Press, Cambridge, United Kingdom.

Jackson RB, Canadell J, Ehleringer JR, Mooney HA, Sala OE, Schulze ED. 1996. A global analysis of root distributions for terrestrial biomes. Oecologia 108:389-411.

Jung M, Reichstein M, Ciais P, Seneviratne SI, Sheffield J, Goulden ML, Bonan G, Cescatti A, Chen J, de Jeu R, Dolman AJ, Eugster W, Gerten D, Gianelle D, Gobron N, Heinke J, Kimball J, Law BE, Montagnani L, Mu Q, Mueller B, Oleson K, Papale D, Richardson AD, Roupsard O, Running S, Tomelleri E, Viovy N, Weber U, Williams C, Wood E, Zaehle S, Zhang K. 2010. Recent decline in the global land evapotranspiration trend due to limited moisture supply. Nature 467:951-4.

Kabat P, Dolman AJ, Ashby M, Gash JC, Wright I, Culf A, Calvet JC, Delire C, Noilhan J, Jochum A, Silva Dias MA, Fisch GA, Santos Alvala RC, Nobre CA, Prince SD, Steininger M. 1999. Use of integrated modelling for experimental design; final report, Wageningen University and Research Centre, Netherlands.

Lachniet MS. 2009. Sea surface temperature control on the stable isotopic composition of rainfall in Panama. Geophys Res Lett 36:L03701. doi:10.1029/2008GL036625.

Loescher HW, Oberbauer SF, Gholz HL, Clark DB. 2003. Environmental controls on net ecosystem-level carbon exchange and productivity in a Central American tropical wet forest. Glob Change Biol 9:396-412.

Malmer A, Murdiyarso D, Bruijnzeel LA, Ilstedt U. 2010. Carbon sequestration in tropical forests and water: a critical look at the basis for commonly used generalizations. Glob Change Biol 16:599-604.

Mauder M, Foken T, Clement R, Elbers JA, Eugster W, Grunwald T, Heusinkveld B, Kolle O. 2008. Quality control of CarboEurope flux data-part 2: inter-comparison of eddycovariance software. Biogeosciences 5:451-62.

Merbold L, Ardo J, Arneth A, Scholes RJ, Nouvellon Y, de Grandcourt A, Archibald S, Bonnefond JM, Boulain N, Brueggemann N, Bruemmer C, Cappelaere B, Ceschia E, ElKhidir HAM, El-Tahir BA, Falk U, Lloyd J, Kergoat L, Le Dantec V, Mougin E, Muchinda M, Mukelabai MM, Ramier D, Roupsard O, Timouk F, Veenendaal EM, Kutsch WL. 2009. Precipitation as driver of carbon fluxes in 11 African ecosystems. Biogeosciences 6:1027-41.

Moureaux C, Debacq A, Bodson B, Heinesch B, Aubinet M. 2006. Annual net ecosystem carbon exchange by a sugar beet crop. Agric For Meteorol 139:25-39.

Nobre CA, Marengo JA, Artaxo P. 2009. Understanding the climate of Amazonia: progress from LBA. In: Keller M, Bustamante M, Gash J, Dias PS, Eds. Amazonia and global change. Washington (DC): American Geophysical Union. p 145-7.
Novick KA, Oren R, Stoy PC, Siqueira MBS, Katul GG. 2009. Nocturnal evapotranspiration in eddy-covariance records from three co-located ecosystems in the Southeastern US: implications for annual fluxes. Agric For Meteorol 149:1491504.

Sakai RK, Fitzjarrald DR, Moraes OLL, Staebler RM, Acevedo OC, Czikowsky MJ, Da Silva R, Brait E, Miranda V. 2004. Land-use change effects on local energy, water, and carbon balances in an Amazonian agricultural field. Glob Change Biol 10:895-907.

Santos AJB, Quesada CA, Da Silva GT, Maia JF, Miranda HS, Miranda AC, Lloyd J. 2004. High rates of net ecosystem carbon assimilation by Brachiara pasture in the Brazilian Cerrado. Glob Change Biol 10:877-85.

Schwarzel K, Punzel J. 2007. Hood infiltrometer-a new type of tension infiltrometer. Soil Sci Soc Am J 71:1438-47.

Scott DF, Bruijnzeel LA, Mackensen J. 2005. The hydrological and soil impacts of forestation in the tropics. Forests, Water and People in the Humid Tropics. New York: Cambridge Univ Press. pp 622-51.

STRI. 2010. Physical Monitoring Program. Smithsonian Tropical Research Institute (STRI).

Tan ZH, Zhang YP, Yu GR, Sha LQ, Tang JW, Deng XB, Song QH. 2010. Carbon balance of a primary tropical seasonal rain forest. J Geophys Res Atmos 115:D00h26. doi:10.1029/ 2009jd012913.

Vanclay JK. 2009. Managing water use from forest plantations. For Ecol Manage 257:385-9.

von Randow C, Manzi AO, Kruijt B, de Oliveira PJ, Zanchi FB, Silva RL, Hodnett MG, Gash JHC, Elbers JA, Waterloo MJ, Cardoso FL, Kabat P. 2004. Comparative measurements and seasonal variations in energy and carbon exchange over forest and pasture in South West Amazonia. Theor Appl Climatol 78:5-26.

Walter H, Lieth H. 1960. Klimadiagramm Weltatlas. Jena: Fischer Verlag.

Webb EK, Pearman GI, Leuning R. 1980. Correction of flux measurements for density effects due to heat and water-vapor transfer. Q J R Meteorol Soc 106:85-100.

Werth D, Avissar R. 2004. The regional evapotranspiration of the Amazon. J Hydrometeorol 5:100-9.

Wilsey BJ, Parent G, Roulet NT, Moore TR, Potvin C. 2002. Tropical pasture carbon cycling: relationships between $\mathrm{C}$ source/sink strength, above-ground biomass and grazing. Ecol Lett 5:367-76.

Wolf S, Eugster W, Potvin C, Buchmann N. 2011a. Strong seasonal variations in net ecosystem $\mathrm{CO}_{2}$ exchange of a tropical pasture and afforestation in Panama. Agric For Meteorol 151:1139-51.

Wolf S, Eugster W, Potvin C, Turner BL, Buchmann N. $201 \mathrm{lb}$ Carbon sequestration potential of tropical pasture compared with afforestation in Panama. Glob Change Biol 17:276380.

Zimmermann B, Elsenbeer H, De Moraes JM. 2006. The influence of land-use changes on soil hydraulic properties: implications for runoff generation. For Ecol Manage 222:29-38. 